\title{
Cadmium accumulation and loss in the Pacific oyster Crassostrea gigas along the west coast of the USA
}

\author{
Tania Y.-T. Ng ${ }^{1,4}$, Chia-Ying Chuang ${ }^{1,5}$, Ian Stupakoff ${ }^{2}$, Aimee E. Christy ${ }^{3}$, \\ Daniel P. Cheney ${ }^{3}$, Wen-Xiong Wang ${ }^{1, *}$ \\ ${ }^{1}$ Department of Biology, The Hong Kong University of Science \& Technology (HKUST), Clear Water Bay, Kowloon, Hong Kong \\ ${ }^{2}$ Integral Consulting Inc., 1205 West Bay Dr., Olympia, Washington 98502, USA \\ ${ }^{3}$ Pacific Shellfish Institute, 120 State Ave. NE \#142, Olympia, Washington 98501, USA \\ ${ }^{4}$ Present address: Department of Biology, McMaster University, 1280 Main Street West, Hamilton, Ontario L8S 4K1, Canada \\ ${ }^{5}$ Present address: Department of Marine Sciences, Texas A\&M University, 5007 Avenue U, Galveston, Texas 77551, USA
}

\begin{abstract}
Oysters can accumulate cadmium (Cd) in very high concentrations in their tissues and there is now increasing concern for the seafood safety of farmed oysters worldwide. Bioaccumulation and biokinetics of $\mathrm{Cd}$ (dietary assimilation, uptake from the dissolved phase, and efflux) were measured in different populations of Pacific oyster Crassostrea gigas collected along the west coast of the USA in 2 different seasons. Triploid juvenile oysters were first transplanted to 5 Washington sites and 1 Oregon site for $3 \mathrm{mo}$, then transported back to the laboratory for tissue Cd measurements and biokinetic experiments. A second group of seed oysters was collected from California and Washington for additional analysis. Oysters from all sites had $\mathrm{Cd}$ concentrations lower than the food standard limit and there was spatial difference in tissue $\mathrm{Cd}$ concentrations. A significant fraction of $\mathrm{Cd}$ was associated with metallothionein-like proteins, implying that the oysters can detoxify $\mathrm{Cd}$ by induction of metallothionein. The difference in Cd dietary assimilation (using diatoms as a food source) and efflux in oysters transplanted to different locations was not significant. The uptake rate constants for $\mathrm{Cd}$ from the dissolved phase, however, differed markedly among the transplanted populations, and appeared to be affected by the oysters' clearance rate, depending on the population. This uptake rate was also negatively affected by the size of oysters. Dietary assimilation of Cd was comparable at diatom food concentrations below 2 to $5 \mathrm{mg} \mathrm{l}^{-1}$, and was lower with ingested sediments than with diatoms. Measurements of $\mathrm{Cd}$ kinetics in different populations of Pacific oysters under a variety of environmental conditions provide an insight into the $\mathrm{Cd}$ accumulation in this commercially important species.
\end{abstract}

KEY WORDS: Pacific oysters - Cadmium - Biokinetics - Accumulation - Subcellular distribution · Metallothionein $\cdot$ Environmental factors $\cdot$ Biological factors

Resale or republication not permitted without written consent of the publisher

\section{INTRODUCTION}

Codex Alimentarius, an international commission responsible for setting food standards and guidelines, has adopted a maximum limit for cadmium (Cd) of $2 \mu \mathrm{g} \mathrm{g}^{-1}$ (wet wt) in marine bivalves excluding oysters and scallops (Codex 2007). However, limited sampling of US west coast commercial shellfish farms indicated that $\mathrm{Cd}$ levels may significantly exceed the $2 \mu \mathrm{g} \mathrm{g}^{-1}$ limit and exceed the US Food and Drug Administration level of concern of $3.7 \mathrm{\mu g} \mathrm{g}^{-1}$ (wet wt) in certain shellfish species and growing areas (USFDA 2005). US Pacific coast shellfish farmers produce $>100$ million pounds ( $>45$ million $\mathrm{kg}$ ) of shellfish annually. The establishment of $2 \mu \mathrm{g} \mathrm{g}^{-1}$ (wet wt) as the maximum limit for $\mathrm{Cd}$ would have significant impacts for shellfish farmers both regionally and globally. 
Laboratory-determined metal biokinetic constants such as the uptake rate constant from the dissolved phase, assimilation efficiencies of metals from diet, and metal efflux rates take into account the metal speciation in water and suspended food particles, animal physiology, and differences in chemical behavior among metals, and can help to understand biological differences in metal accumulation among aquatic organisms. These constants are derived for the biokinetic model that is used to predict metal concentrations in aquatic environments (Roditi et al. 2000, Ke \& Wang 2001, Luoma \& Rainbow 2005, Pan \& Wang 2008a, Wang \& Rainbow 2008). In addition, by determining these constants, and with knowledge of ambient metal concentrations, the significance of each metal exposure route can be delineated.

Over the past $15 \mathrm{yr}$, metal biokinetics have been widely studied in marine bivalves under different environmental and biological conditions (reviewed by Wang 2003, 2009). In addition, there have been a few studies to contrast the differences in metal biokinetics from different populations of marine invertebrates originating from different environments or contaminated histories (Blackmore \& Wang 2003, Ng \& Wang 2005a,b, Rainbow et al. 2009). From these studies, little is known on metal dietary assimilation in the Pacific oyster Crassostrea gigas, which is an important farmed bivalve species along the west coast of North America and a valuable shellfish resource. Earlier studies measured Cd uptake in oysters over long-term exposure, or $\mathrm{Cd}$ elimination in field-transplanted oysters (Ayling 1974, Zaroogian \& Cheer 1976, Denton \& BurdonJones 1981, Lim et al. 1998, Wallner-Kersanach et al. 2000, Geffard et al. 2002, Boisson et al. 2003). Metal bioavailability may be different for oysters from diverse environments because of the variation in local metal geochemistry and the physiology of oysters adapted to these environments.

In order to understand $\mathrm{Cd}$ accumulation in Crassostrea gigas, we transplanted oysters from shellfish farms to 6 different sites on the US west coast for a period of 3 mo and collected a set number of oysters for laboratory experiments. In the laboratory, the uptake and efflux kinetics of $\mathrm{Cd}$ in oysters were determined. The objectives were to determine if there were differences in Cd kinetics among these oyster populations, and to examine the effects of environmental factors (dissolved Cd concentrations, and different food concentrations and food types) and biological factors (i.e. body size and ploidy) on Cd uptake. We also quantified metallothionein (MT) concentrations and subcellular $\mathrm{Cd}$ distributions in these field-collected oysters in order to determine differences in metal detoxification among populations. Other field parameters, such as Cd concentration and growth rate of oysters, that con- tributed to the difference in Cd accumulation were also measured for developing the biokinetic model. However, they were not within the scope of the present study, and thus results will not be described in the present paper.

\section{MATERIALS AND METHODS}

Oyster collection. In April 2005, a batch of 2000 triploid, $9.5 \mathrm{~mm}$ long Crassostrea gigas seeds were collected from Oakland Bay (OAK) nursery, Washington (Fig. 1). Seeds were split into 6 groups and placed into mesh seed bags contained within on-bottom cages at 5 Washington-state sites (Eld Inlet-ELD, Hamma Hamma-HAM, Samish Bay-SME, Thorndyke Bay$\mathrm{SQB}$, and Willapa Bay-WBC) and 1 Oregon site at Netarts Bay-NET (Fig. 1). All oyster seeds in this group were a cross between a diploid family and a chemically induced tetraploid family. In general, the ambient dissolved Cd concentrations in all sites varied from 41 to $88 \mathrm{ng} \mathrm{l}^{-1}$ (I. Stupakoff unpubl. data). The average water temperature varied between 6 and $19^{\circ} \mathrm{C}$ (winter low, summer high) and peaked at $>20^{\circ} \mathrm{C}$ in summer at some sites. Growth of oysters varied from 0.18 to $0.32 \mathrm{~mm} \mathrm{~d}^{-1}$. In July 2005, after a 3 mo transplant and acclimation period, oysters from each site (13 to $152 \mathrm{~mm}$ in length) were shipped overnight to the Coastal Marine Laboratory at the Hong Kong University of Science and Technology (HKUST) for fieldsample measurements and laboratory biokinetic experiments on Cd. A separate batch of seed oysters (15 to $30 \mathrm{~mm}$ in length) was collected in October 2005 and sent to HKUST for additional Cd experiments. These included diploid seeds from Humboldt Bay, California (HUM) and SQB, and diploid and triploid seeds from OAK (OAK D and OAK T, respectively) (Fig. 1). This second batch was used to determine if there were any differences in $\mathrm{Cd}$ kinetics, and biological differences such as condition index, clearance rate, and tissue concentrations between the triploid and diploid populations. All oysters were acclimated in the laboratory for $1 \mathrm{wk}$ at salinity 26 and temperature $24 \pm 1^{\circ} \mathrm{C}$ prior to the experiments. They were continuously fed with the diatom Thalassiosira pseudonana (clone $3 \mathrm{H}$ ) during the acclimation period.

Field-sample measurements. Cd concentrations in soft tissue and subcellular fractions: From each of the July and October populations, 10 individual oysters ( 0.2 to $1.5 \mathrm{~g}$ tissue wet $\mathrm{wt}$ ) were sampled for quantification of $\mathrm{Cd}$ concentration in the soft tissues. Oysters were dissected and the soft tissues were gently blotted in clean paper towels and individually placed into acid-cleaned glass tubes. The wet weight was determined and the dry weight was obtained by drying the 


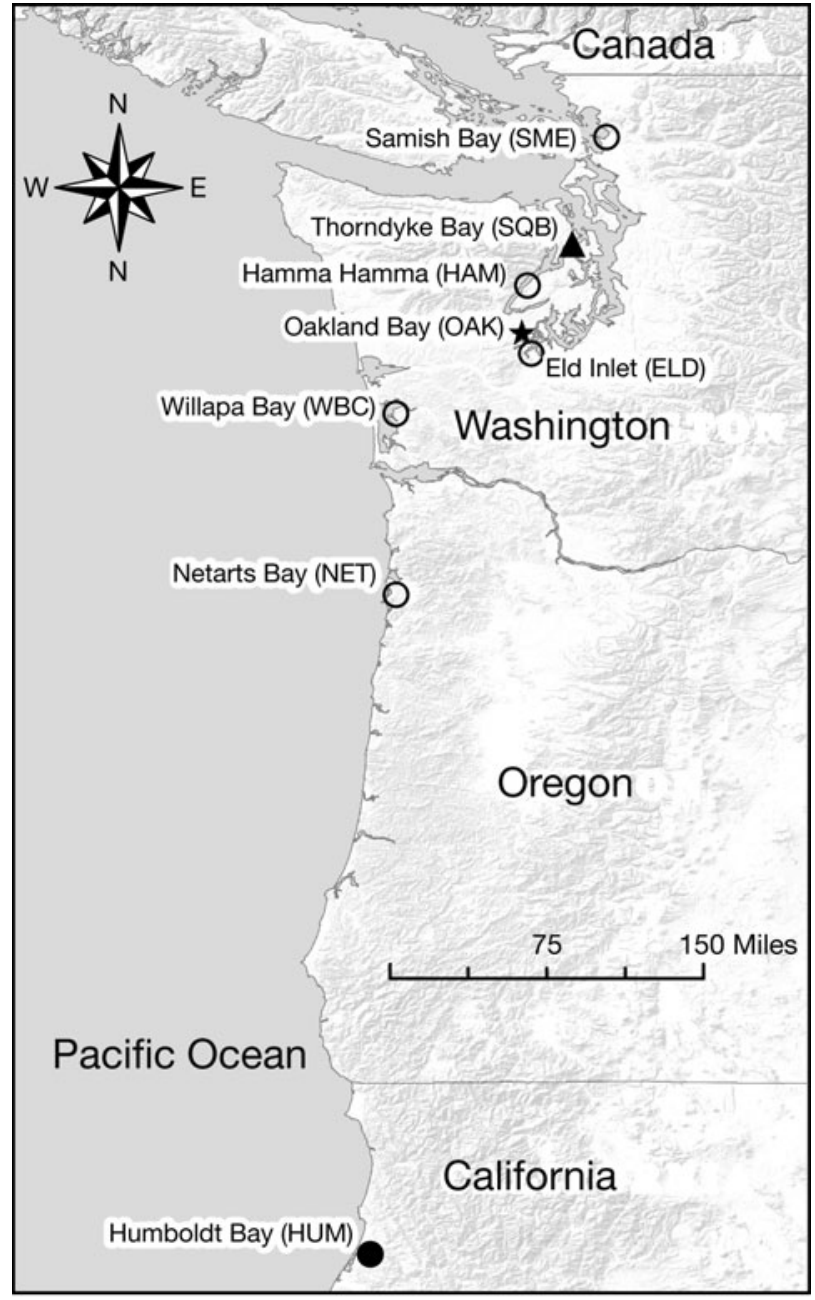

Fig. 1. Crassostrea gigas. Sampling sites from oyster farms along the US west coast (o). Oyster seed from Oakland Bay $(\mathrm{OAK})(\star)$ transplanted to 6 locations: Netarts Bay (NET), Willapa Bay (WBC), Samish Bay (SME), Thorndyke Bay (SQB), Hamma Hamma (HAM), and Eld Inlet (ELD). After 3 mo of transplantation, they were collected for experiments in July 2005. Another group of oyster seed was collected from Humboldt Bay (HUM •), OAK, and SQB in October 2005. $\mathrm{SQB}$ is marked with a $\boldsymbol{\Delta}$ as oysters were collected from this site in both July and October

tissue at $80^{\circ} \mathrm{C}$ to constant weights. Dried tissues were then digested by adding $2 \mathrm{ml}$ of concentrated ultrapure $\mathrm{HNO}_{3}$ and gently heating the sample at $60^{\circ} \mathrm{C}$ for $1 \mathrm{~d}$, then $110^{\circ} \mathrm{C}$ until the tissue was completely digested. The digests were subsequently diluted with NANOpure ${ }^{\circledR}$ water to appropriate concentrations that were measured by inductively coupled plasma-mass spectroscopy (ICP-MS) or polarized Zeeman atomic absorption spectrophotometer. Blank was run every 20 samples and recovery of $\mathrm{Cd}$ concentration was checked with a standard reference material (1566b Oyster tissue,
US Department of Commerce, Technology Administration, National Institute of Standards and Technology, Gaithersburg, MD) in every run. Recovery of Cd was $97.9 \pm 6.4 \%$. The $\mathrm{Cd}$ tissue concentrations were expressed as $\mu \mathrm{g} \mathrm{g}^{-1}$ dry wt and wet wt.

The subcellular concentration of $\mathrm{Cd}$ in oysters was quantified only in the October population using a modified method of Wallace et al. (2003). From each population, 5 replicated oysters ( 0.2 to $0.6 \mathrm{~g}$ tissue wet wt) were dissected and the wet weights of the soft tissue were measured. Afterwards, the soft tissue was homogenized in $2 \mathrm{ml}$ of $20 \mathrm{mM}$ Tris-base buffer ( $\mathrm{pH}$ 8.6) with $10 \mathrm{mM}$ antioxidant 2-mercaptoethanol and $0.1 \mathrm{mM}$ freshly prepared phenylmethylsulfonyl fluoride (PMSF), a protease inhibitor. The homogenate was centrifuged at $1500 \mathrm{~g}\left(15 \mathrm{~min}\right.$ at $\left.4^{\circ} \mathrm{C}\right)$. The supernatant was further centrifuged at $100000 \mathrm{~g}$ for $30 \mathrm{~min}$ at $4^{\circ} \mathrm{C}$ to separate the cytosol from the organelles (ORG), i.e. pellets containing nuclear, mitochondrial, and microsomal fractions (intracellular fractions). Following heat treatment $\left(10 \mathrm{~min}\right.$ at $\left.80^{\circ} \mathrm{C}\right)$ and ice-cooling $(15 \mathrm{~min})$, the $100000 \mathrm{~g}$ supernatant was centrifuged again at $5000 \mathrm{~g}$ for $10 \mathrm{~min}$ at $4^{\circ} \mathrm{C}$. The final supernatant contained the heat-stable proteins or MT-like proteins (MTLPs) and the pellets contained the heat-sensitive proteins (HSPs) due to heat denaturation. The $1500 \mathrm{~g}$ pellets that included the tissue fragments and cellular debris were dissolved in $1 \mathrm{~N}$ sodium hydroxide at $80^{\circ} \mathrm{C}$, then centrifuged at $5000 \mathrm{~g}$ for $10 \mathrm{~min}$ to separate the cellular debris and metal-rich granules (MRG). Cd concentrations in the 5 subcellular fractions (MTLP, HSP, ORG, cellular debris, and MRG) were determined as described in the previous paragraph, and were expressed as $\mu \mathrm{g} \mathrm{g}^{-1}$ wet wt of the whole soft tissue.

MT concentration: The MT concentration in the oysters was determined in the October population using a modified silver saturation method (Scheuhammer \& Cherian 1986, 1991, Leung \& Furness 1999). The wet weights of 5 individuals ( 0.3 to $1.5 \mathrm{~g}$ tissue wet wt) were determined after dissection. The replicated tissues were then homogenized individually in $2 \mathrm{ml}$ Trisbase buffer (prepared as in 'Cd concentrations in soft tissue and subcellular fractions' above), followed by centrifugation at $20000 \mathrm{~g}$ for $20 \mathrm{~min}$ at $4^{\circ} \mathrm{C}$. Subsequently, $0.3 \mathrm{ml}$ of the supernatant was mixed with $0.5 \mathrm{ml}$ of $20 \mu \mathrm{g}$ silver (Ag) $\mathrm{ml}^{-1}$ with the radioisotope

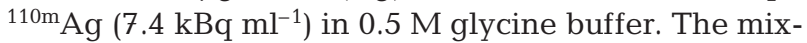
ture was incubated at room temperature for $10 \mathrm{~min}$ to saturate the MT with excessive Ag. The Ag not bound with MT was then removed by adding $0.1 \mathrm{ml}$ rabbit blood cell hemolysate, heating for $5 \mathrm{~min}$ at $100^{\circ} \mathrm{C}$ and centrifuging for $5 \mathrm{~min}$ at $785 \mathrm{~g}$. The addition of hemolysate, heating, and centrifugation were repeated twice. The supernatant obtained was further centrifuged for $20 \mathrm{~min}$ at $17100 \mathrm{~g}$ and the amount of $\mathrm{Ag}$ remaining in 
the final supernatant was quantified for ${ }^{110 \mathrm{~m}} \mathrm{Ag}$. The amount of MT was calculated as 3.55 times the amount of Ag in the final supernatant and expressed as $\mu \mathrm{g} \mathrm{g}^{-1}$ wet wt of the oyster (Scheuhammer \& Cherian 1991).

Clearance rate and condition index: From each of the July and October populations, 10 oysters (0.1 to $0.5 \mathrm{~g}$ tissue wet wt) were brought to a temperaturecontrolled laboratory $\left(20\right.$ to $22^{\circ} \mathrm{C}$ ) $30 \mathrm{~min}$ before the experiment. They were placed individually into $1.5 \mathrm{l}$ of $0.22 \mu \mathrm{m}$ filtered seawater within a polypropylene beaker. After the oysters opened and pumped normally (usually within $10 \mathrm{~min}$ ), the diatoms Thalassiosira pseudonana (filtered from their growth medium) were added into each beaker at a concentration of ca. $10^{4}$ cells $\mathrm{ml}^{-1}$. Algae were kept in suspension by a magnetic stirrer. Immediately after adding the algae, and 20 and 40 min later, a $10 \mathrm{ml}$ aliquot water sample was removed and cell density counted using a Coulter counter (model Z1). After the clearance rate measurements, the oysters were dissected, and soft tissues and shells were dried at $80^{\circ} \mathrm{C}$ overnight to obtain dry weights. Clearance rate was calculated by the following equation:

$$
\mathrm{CR}=V \times\left[\ln \left(C_{1}\right)-\ln \left(C_{2}\right)\right] / t
$$

where $\mathrm{CR}$ is the clearance rate $\left(\mathrm{l} \mathrm{g}^{-1} \mathrm{~h}^{-1}\right), C_{1}$ is the cell density (cell ml-1) at time $1, C_{2}$ is the cell density at time 2, $t$ is time of measurement increment (i.e. $t_{2}-t_{1}$, in $\mathrm{h}$ ), and $V$ is the volume of water (l). CR for each individual was calculated from the mean of 2 consecutive measurements. The condition index was expressed as $100 \% \times$ (tissue dry wt/shell dry wt).

Laboratory experiments for measuring Cd biokinetics. All the oysters for measuring $\mathrm{Cd}$ biokinetics were transported to a temperature-controlled laboratory $\left(20\right.$ to $\left.22^{\circ} \mathrm{C}\right)$ half an hour before radiotracer experiments to allow for adaptation to the change in temperature between aquarium tanks $\left(24^{\circ} \mathrm{C}\right)$ and laboratory.

Assimilation efficiency (AE): AE for Crassostrea gigas fed on diatoms and sediment were determined after methods of Wang \& Fisher (1996). AE of Cd from diatom food was measured in both the July and October populations. Thalassiosira pseudonana (clone $3 \mathrm{H}$ ) were radiolabeled with gamma-emitting ${ }^{109} \mathrm{Cd}$ by addition of ${ }^{109} \mathrm{Cd}$ (in $0.1 \mathrm{~N} \mathrm{HCl}$ ) to the growth media

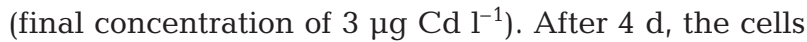
had undergone $>4$ divisions and were considered uniformly labeled. These cells were collected on a $3 \mu \mathrm{m}$ polycarbonate membrane and resuspended in $50 \mathrm{ml}$ of water twice to wash away the potential $\mathrm{Cd}$ in the nutrient medium and adsorbed $\mathrm{Cd}$ to the cells, before being added to a beaker with $500 \mathrm{ml}$ filtered seawater. Ten individuals from each oyster population (shell length ca. 20 to $30 \mathrm{~mm}$ ) were placed in each beaker and at 10 min intervals, diatoms were added to maintain a cell density of $4 \times 10^{4}$ to $5 \times 10^{4}$ cells ml ${ }^{-1}$ or 1 to $1.2 \mathrm{mg} \mathrm{l}^{-1}$. After $30 \mathrm{~min}$ of radioactive feeding, oysters were rinsed in seawater and analyzed for radioactivity. Potential radiotracer uptake by the oysters from the aqueous phase (due to desorption from the radiolabeled diatoms) was considered negligible compared with the total ingestion of radiotracers from diatoms within the $30 \mathrm{~min}$ period. Five individuals that obtained the highest counts of ${ }^{109} \mathrm{Cd}$ after feeding on the radiolabeled diatoms were selected and placed into separate polypropylene beakers $(180 \mathrm{ml}$ seawater) held in a 201 enclosed recirculating flow-through aquarium containing non-radioactive seawater. T. pseudonana was fed at a ration of about 1 to $2 \%$ of oyster tissue dry wt $\mathrm{d}^{-1}$. In the July experiment, radioactivity retained in the oysters was measured over a $60 \mathrm{~h}$ depuration period at intervals from 1.5 to $12 \mathrm{~h}$. In the October AE experiment, the depuration period was shortened because the percentage of initial radioactivity retained in the oysters after the initial $24 \mathrm{~h}$ of depuration became constant. Any feces egested by the animals during the depuration period were collected regularly to minimize desorption of radiotracers from the fecal material into the water and to minimize the potential for oyster uptake of $\mathrm{Cd}$ from the dissolved phase. AE is determined as the percentage of initial radioactivity retained in the oysters after $24 \mathrm{~h}$ depuration.

The AE of $\mathrm{Cd}$ by the oysters in sediment was measured similar to the procedures described in the previous paragraph and it was only measured in the July population. Dry oxic sediment (30 mg) from surface sediment collected from each oyster sampling site was radiolabeled with $185 \mathrm{kBq}{ }^{109} \mathrm{Cd}\left(3 \mu \mathrm{g} \mathrm{l}{ }^{-1} \mathrm{Cd}\right)$ in $10 \mathrm{ml}$ filtered seawater, and the $\mathrm{pH}$ was neutralized to 8 with $1 \mathrm{~N} \mathrm{NaOH}$. The radiolabeling lasted for $3 \mathrm{~d}$. The sediment was collected by centrifugation at $2180 \mathrm{~g}$ for 5 min twice and resuspended in $1.5 \mathrm{ml}$ filtered seawater before the assimilation measurements. The particles were then added to 11 of filtered seawater at a particle load of $10 \mathrm{mg} \mathrm{l}^{-1}$. Individual oysters (shell length 20 to $30 \mathrm{~mm}$ ) were allowed to feed on the radiolabeled particles for $30 \mathrm{~min}$, and the sediment was added into each treatment at $t=0,10$, and $20 \mathrm{~min}$, during which time no radiolabeled feces were produced. Afterwards, the oysters were removed from the feeding beakers, rinsed, and radioassayed. Then they were allowed to depurate $\mathrm{Cd}$, fed diatoms at 1 to $2 \%$ body ration $\mathrm{d}^{-1}$, and regularly measured for radioactivity.

We selected 2 populations, the July SQB population and the October HUM population, to determine the effect of food concentration on Cd AE. We used 4 different concentrations of Thalassiosira pseudonana: 0.2 , $0.5,2$, and $5 \mathrm{mg} \mathrm{l}^{-1}$, which encompassed the food concentrations below and above the pseudofeces produc- 
tion (Widdows et al. 1979, Wang 2002). A higher concentration, $10 \mathrm{mg} \mathrm{l}^{-1}$, was only tested in the October experiment, whereas the highest concentration of food for the July experiment was $5 \mathrm{mg} \mathrm{l}^{-1}$. Five individual oysters (shell length ca. 20 to $30 \mathrm{~mm}$ ) were used for each diatom concentration treatment and they were depurated in the polypropylene beakers with recirculating water after the pulse feeding. To maintain the food concentration in the system, $T$. pseudonana was continuously pumped to the recirculating water by a peristaltic pump. Water samples were regularly taken for food concentration measurement by a Coulter counter. Other procedures for measuring radioactivity and feeding during the depuration period followed the description above.

Uptake rate from the dissolved phase: Stable $\mathrm{Cd}$ at dissolved concentrations of $0.5,2,10$, and $50 \mu \mathrm{g} \mathrm{l}^{-1}$ with added ${ }^{109} \mathrm{Cd}$ activity of $3.7 \mathrm{kBq}^{-1}$ (equivalent to stable $\mathrm{Cd}$ of $0.03 \mu \mathrm{g}^{-1}$ ) were equilibrated overnight before the uptake experiments. The stable Cd concentrations were within 10 to $100 \times$ higher than the environmen-

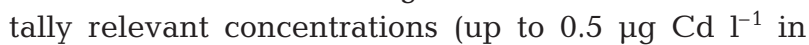
uncontaminated water; Luoma \& Rainbow 2008). A range of low and high $\mathrm{Cd}$ concentrations were chosen to quantify the uptake rate constant, which should be independent of the $\mathrm{Cd}$ ambient concentration (see 'Results'). From each of the July and October populations, 10 oysters ( 0.1 to $0.5 \mathrm{~g}$ tissue wet wt) were carefully cleaned and placed individually into $200 \mathrm{ml}$ of $0.22 \mu \mathrm{m}$ filtered seawater with different dissolved concentrations of $\mathrm{Cd}$, for $1 \mathrm{~h}$. A short exposure time $(1 \mathrm{~h})$ was chosen to measure uptake rate so that the efflux of initial dissolved $\mathrm{Cd}$ uptake had minimal influence on tissue concentration. In addition, the decrease in dissolved metal concentration in ambient experimental water could be minimized due to uptake by the oysters during the short exposure period. No mortality was observed during the short exposure period.

After the exposure, the oysters were dissected and the radioactivity of the soft tissues was measured. The tissues were then dried at $80^{\circ} \mathrm{C}$ overnight to determine the dry weights. The influx rate was calculated as the amount of dissolved $\mathrm{Cd}$ accumulated by the oysters over time and was normalized to per gram tissue dry weight per hour $\left(\mathrm{ng} \mathrm{g}^{-1} \mathrm{~h}^{-1}\right)$. The uptake rate constant from the dissolved phase $\left(\mathrm{l} \mathrm{g}^{-1} \mathrm{~d}^{-1}\right)$ was calculated by dividing the influx rate over the dissolved Cd concentration. The rates were subsequently compared among the experimental populations.

To evaluate the effect of body size on dissolved $\mathrm{Cd}$ uptake, 20 oysters (shell length 13 to $152 \mathrm{~mm}$; 0.1 to $37 \mathrm{~g}$ tissue wet weight) from each of the July populations were used for the experiment. The oysters were exposed to $3.7 \mathrm{kBq}^{-1}$ (equivalent to stable $\mathrm{Cd}$ of $\left.0.03 \mu \mathrm{g} \mathrm{l}^{-1}\right){ }^{109} \mathrm{Cd}_{\text {and }}$ stable $\mathrm{Cd}\left(2 \mu \mathrm{g} \mathrm{l}^{-1}\right)$, in $200 \mathrm{ml}$ filtered seawater for $1 \mathrm{~h}$. Then the oyster tissue was dissected, measured for radioactivity, and dried as in the procedures described for measuring the uptake rate from different $\mathrm{Cd}$ concentrations. Regression of uptake rate against body size (g) was tested. Since the October oysters had a smaller size range $(0.1$ to $1.5 \mathrm{~g}$ tissue wet wt), all oysters from populations with variable size ranges that were exposed to different $\mathrm{Cd}$ concentrations were pooled from the October 2005 dissolved uptake experiment for data analysis.

Efflux rate: The efflux rate was determined for the July populations only. From each population, 10 oysters (shell length ca. 20 to $30 \mathrm{~mm}$ ) were maintained in clean filtered seawater and fed with ${ }^{109} \mathrm{Cd}$ radiolabeled Thalassiosira pseudonana for $2 \mathrm{~h}$ each day. Diatoms had been previously radiolabeled with ${ }^{109} \mathrm{Cd}$ for $4 \mathrm{~d}$ (as described in 'Assimilation efficiency (AE)' above) and were filtered from the growth medium, rinsed, and resuspended in clean seawater before being fed to the oysters. The seawater was renewed every day after the radioactive feeding. Following $6 \mathrm{~d}$ feeding on radiolabeled food, the oysters were radioassayed and then placed into an enclosed recirculating seawater aquarium tank (as described in the assimilation efficiency experiments) to depurate the ${ }^{109} \mathrm{Cd}$ for $21 \mathrm{~d}$. During the course of depuration, the aquarium seawater was changed every $2 \mathrm{~d}$, and nonradioactive T. pseudonana was fed twice daily at a ration of about $2 \%$ dry wt $\mathrm{d}^{-1}$. The radioactivity retained in each individual was counted periodically, and fecal pellets were collected frequently. On the first and the last day of depuration, 3 individuals from each population were dissected to determine the radioactivity in the shell and soft tissue. Efflux rate constant $\left(k_{\mathrm{e}}, \mathrm{d}^{-1}\right)$ was determined from the slope of the linear regression between the $\ln \% \mathrm{Cd}$ retained in the oysters against the depuration time (d). Since depuration of $\mathrm{Cd}$ of all populations was linear over time, $k_{\mathrm{e}}$ was calculated from Days 0 to 21 .

Radioactivity measurement and statistical analysis. ${ }^{109} \mathrm{Cd}$ radioactivity was measured by a gamma counter (Wallac 1480 Wizard 3', Perkin Elmer). Spillover from the higher energy window to the low energy window of radioisotopes was corrected and all counts were related to standards for each isotope. The gamma emissions of ${ }^{109} \mathrm{Cd}$ were determined at $88 \mathrm{keV}$. Counting times in all samples were adjusted so that the propagated counting errors were typically $<5 \%$.

All data were checked for normal distribution and homogeneity. Statistical difference among different treatments was tested by 1 -way ANOVA $(\mathrm{p}<0.05)$ and significant differences between populations were analyzed by Tukey's multiple comparison post hoc tests. Linear regression analysis was performed for the relationships between dissolved uptake rate and Cd concentration or body size. 


\section{RESULTS}

\section{Field-sample measurements}

Cd concentrations in soft tissue and subcellular fractions

The regression was tested separately for each population and the regression coefficient $\left(\mathrm{r}^{2}\right)$ between wet and dry weight of oyster tissue in all populations was $\geq 0.69$, indicating a high correspondence of tissue wet and dry weights. The tissue wet to dry weight ratio varied between 6 and 15 (WBC: 15; SME: 7; HAM: 13; ELD: 10; July SQB: 7; NET: 6; HUM: 11; OAK D: 8; OAK T: 6; October SQB: 7). The Cd concentrations in the soft tissue of both July and October oyster populations ranged from 3 to $8 \mu \mathrm{g} \mathrm{g}^{-1}$ dry wt (0.3 to $0.8 \mu \mathrm{g} \mathrm{g}^{-1}$ wet wt; Fig. 2 ). The highest concentrations collected in July were found in the SQB and HAM populations with about $0.6 \mathrm{\mu g} \mathrm{g}^{-1}$ wet wt whereas WBC and NET had the lowest Cd concentration by wet weight $\left(0.3 \mu \mathrm{g} \mathrm{g}^{-1}\right)$ (Fig. 2). Cd accumulation followed this sequence: $\mathrm{SQB}=\mathrm{HAM}>\mathrm{ELD}=\mathrm{SME}>$ $\mathrm{WBC}=\mathrm{NET}$. In October, HUM oysters had the lowest $\mathrm{Cd}$ accumulation $\left(0.4 \mu^{-1} \mathrm{~g}^{-1}\right.$ wet wt) whereas the other populations had comparable $\mathrm{Cd}$ concentrations $\left(0.8 \mu \mathrm{g} \mathrm{g}^{-1}\right.$ wet wt). The pattern for $\mathrm{Cd}$ concentration on dry weight base was different from wet weight, probably due to the variable water contents in the oyster tissues among populations. The sequence of tissue $\mathrm{Cd}$ concentrations by dry weight for the July populations was NET = $\mathrm{HAM} \geq \mathrm{SQB} \geq \mathrm{WBC}=\mathrm{ELD}=\mathrm{SME}$, with $\mathrm{SQB}$ oysters having an intermediate concentration of $\mathrm{Cd}$ that did not differ from the other groups. The sequence by dry weight for the October population was OAK D $>$ HUM = OAK T = SQB. SQB oysters collected in July and October both had comparable Cd concentrations by dry and wet weights, whereas October OAK D oysters had significantly higher Cd concentration than the OAK T ones by dry weight ( $p<0.01$ ), but not by wet weight $(p=0.68)$.

Subcellular $\mathrm{Cd}$ concentration was measured for the October population. The oyster tissue was fractioned into soluble (MTLP, HSP, and ORG) and insoluble fractions (MRG and cellular debris) for Cd concentration analysis. Since the concentration of $\mathrm{Cd}$ in the cellular debris fraction was too low for detection, it is not presented here. Generally, concentration of Cd was similar (0.1 to $0.4 \mu \mathrm{g}$ $\mathrm{g}^{-1}$ wet wt) in all subcellular fractions $(\sim 75 \%$ in soluble fractions) except the OAK D and OAK T oysters, which had higher $\mathrm{Cd}$ in the soluble fractions ( 86\% in soluble fractions), especially in the MTLP (Fig. 3).

\section{MT concentrations}

MT concentration was also only measured for the October populations. MT concentration in the oysters varied between 57.4 and $73.0 \mu \mathrm{g} \mathrm{g}^{-1}$ wet wt and did not

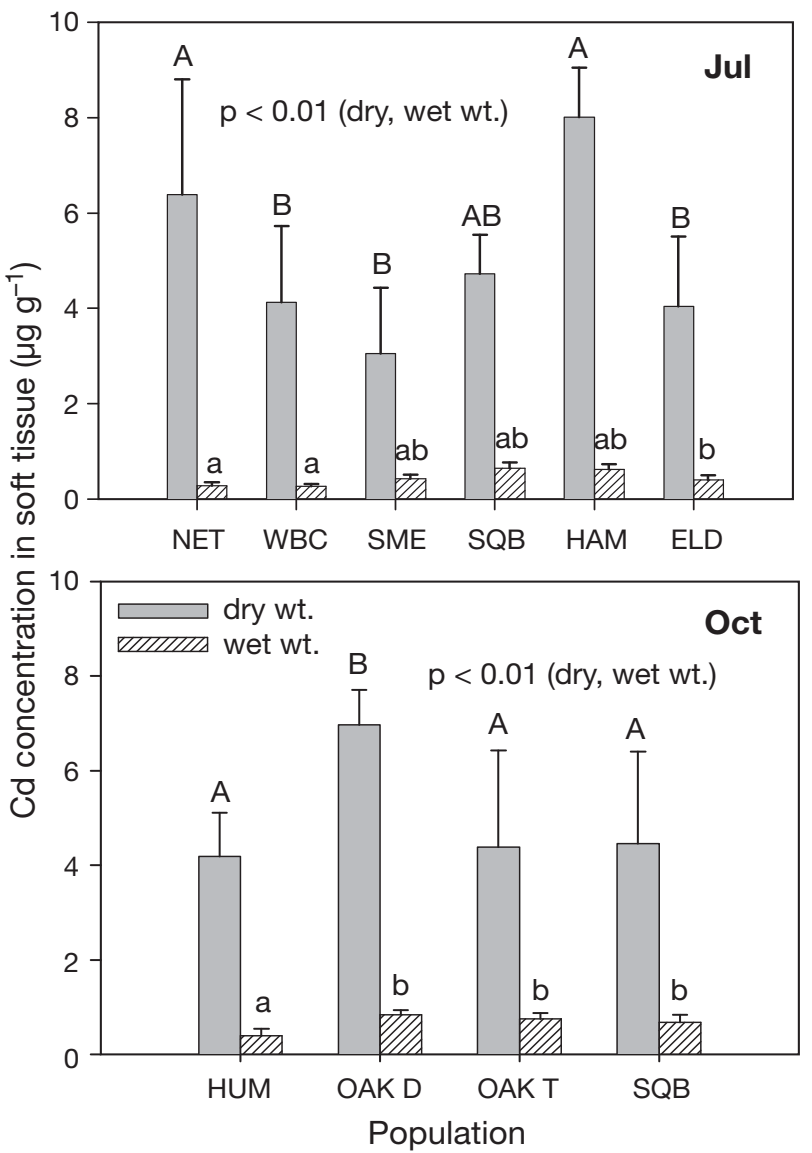

Fig. 2. Crassostrea gigas. Cd concentration (mean $\pm \mathrm{SD} ; \mathrm{n}=$ 10 ) in the soft tissue of oysters collected in July (upper panel) and October (lower panel). Significant differences among populations were tested by ANOVA ( $<<0.05)$; populations with the same letter did not differ significantly (Tukey's multiple comparison post hoc test; $\mathrm{p}>0.05)$. OAK D: diploid seeds and OAK T: triploid seeds from Oakland Bay. See Fig. 1 for other site abbreviations

differ significantly among populations (Fig. 4; p > 0.05), although a similar trend of higher concentrations was observed in OAK D and OAK T populations. This may explain the higher $\mathrm{Cd}$ concentration associated with MTLP in the 2 populations, as Cd has a high affinity to bind to MT.

\section{Clearance rate and condition index}

The July oysters had comparable clearance rates $(8.0$ to $14.0 \mathrm{l} \mathrm{g}^{-1} \mathrm{~h}^{-1}$ ), with the exception of the ELD population, which had a very low clearance rate of $0.9 \mathrm{l} \mathrm{g}^{-1} \mathrm{~h}^{-1}$ (Fig. 5). The ELD population had a high mortality in the laboratory and the low filtration rate could be associated with high sensitivity to the stress imposed during transport and acclimation to the new laboratory environment. The October populations survived well 
Fig. 3. Crassostrea gigas. Cd concentrations (mean $\pm \mathrm{SD} \mathrm{n}=5$ ) in the subcellular fractions from the October population of oysters: metallothionein-like proteins (MTLP; upper left), heat-sensitive proteins (HSP; upper right), organelles (ORG; lower left), and metal-rich granules (MRG; lower right). Significant differences among populations were tested by ANOVA $(\mathrm{p}<0.05)$; populations with the same letter did not differ significantly (Tukey's multiple comparison post hoc test; $\mathrm{p}>0.05)$. HUM: Humboldt Bay, OAK D: diploid seeds from Oakland Bay, OAK T: triploid seeds from Oakland Bay, SQB: Thorndyke Bay

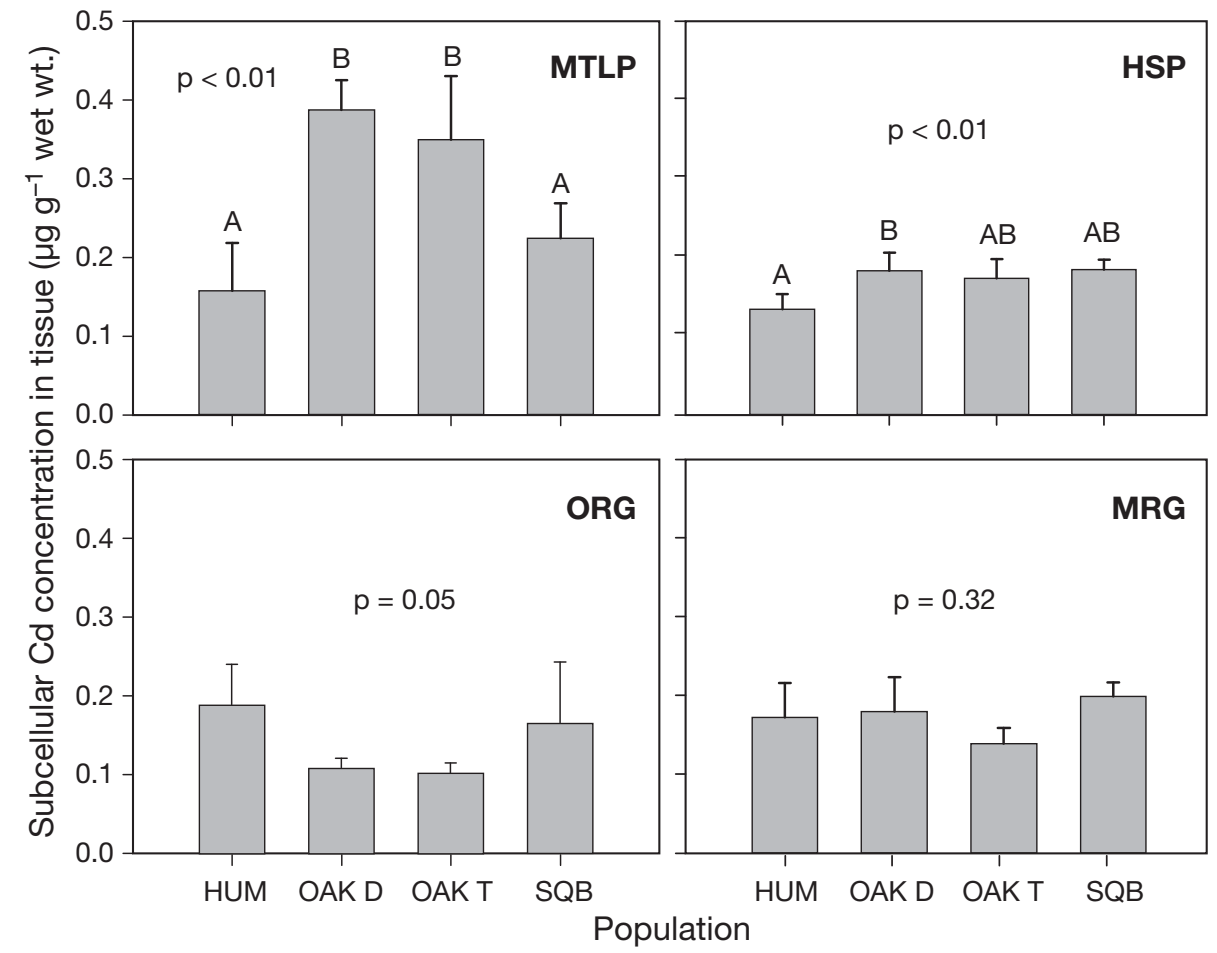

Condition index was similar among the July populations, with the exception of SQB oysters when compared to WBC and NET oysters (Fig. 5). The condition index of the ELD population was similar to the other oysters, although it had the highest mortality because condition index was determined from the samples that were stored immediately after transportation to the laboratory. Therefore, it is evident that ELD oysters survived well in the field. The condition index of the October population was similar to the July population and OAK T oysters had a higher condition index than the OAK D ones.

\section{Laboratory experiments for measuring Cd biokinetics}

\section{Assimilation efficiency}

After a pulse ingestion of radiolabeled diatoms or sediments, the oysters depurated $\mathrm{Cd}$ in 2 consecutive stages. The first depuration stage occurred within the first $6 \mathrm{~h}$, where a steep negative slope showed that the oysters depurated most of the unassimilated $\mathrm{Cd}$ from their bodies (Fig. 6). The second depuration stage occurred much slower $(>6 \mathrm{~h})$ as shown by the flat slopes in Fig. 6. Subsequently, the percentage of $\mathrm{Cd}$ retained in the oysters was almost constant over the depuration period ( $>6 \mathrm{~h}$, slow compartment). AEs of $\mathrm{Cd}$ from diatoms in the July populations were about $44 \%$ and it was comparable among populations

Fig. 4. Crassostrea gigas. Metallothionein (MT) concentration (mean $\pm \mathrm{SD}_{i} \mathrm{n}=5$ ) in oysters from the October population. Significant differences among populations were tested by ANOVA $(p<0.05)$. HUM: Humboldt Bay, OAK D: diploid seeds from Oakland Bay, OAK T: triploid seeds from Oakland Bay, SQB: Thorndyke Bay 


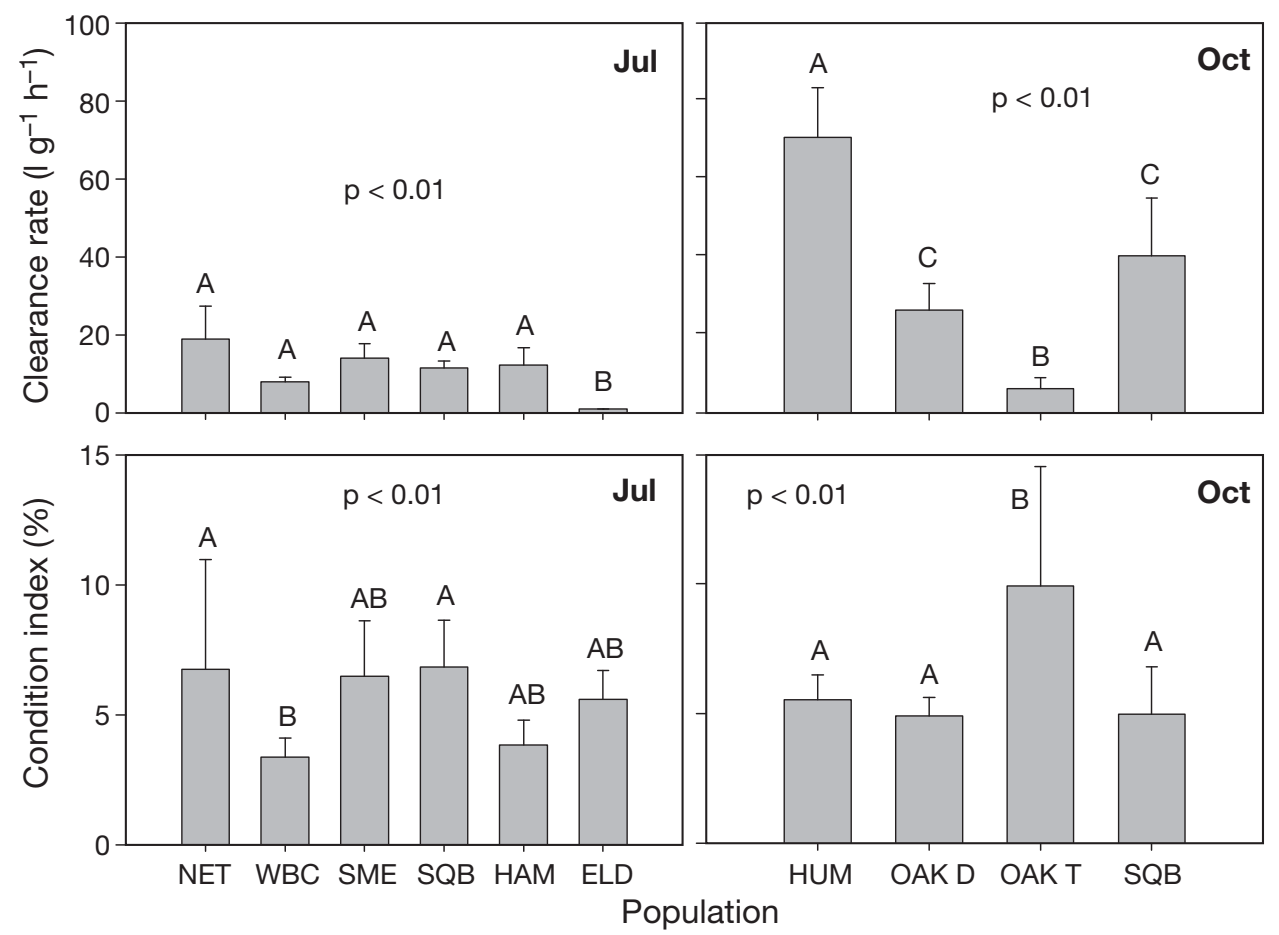

Fig. 5. Crassostrea gigas. Clearance rate (mean $\pm \mathrm{SD}_{;} \mathrm{n}$ $=8$; upper panels) and condition index (mean $\pm \mathrm{SD} ; \mathrm{n}=10$; lower panels) of the July (left panels) and October (right panels) populations. Condition index was calculated as $100 \% \times$ (tissue dry wt/shell dry wt). Significant differences among populations were tested by ANOVA ( $\mathrm{p}<$ 0.05); populations with the same letter did not differ significantly (Tukey's multiple comparison post hoc test; $\mathrm{p}>$ 0.05). OAK D: diploid seeds and OAK $\mathrm{T}$ : triploid seeds from Oakland Bay. See Fig. 1 for other site abbreviations
(Table 1, Fig. 6; p > 0.05). In general, the October populations (48 to $64 \%$ ) had slightly higher AEs than the July populations (39 to $48 \%$ ). SQB oysters from the July population had lower AE (47.6 $\pm 5.7 \%)$ than the October population $(64.2 \pm 4.8 \%)$ (Table 1, Fig. $6 ; \mathrm{p}<0.01)$. The October populations can be grouped according to their AEs: $\mathrm{SQB}=\mathrm{HUM}>$ OAK D = OAK T.

Oysters fed sediment diets had lower Cd AEs than oysters fed diatom diets (Table 1, Fig. 6). The average Cd AEs from sediment was $20.4 \%$, ranging from 8.6 to $29.9 \%$. The SQB population did not feed on the sediment and therefore no AE was determined. The highest Cd uptake from the sediment diet was $29.9 \%$ for the ELD population. However, these oysters still had $\sim 7 \%$ lower AE than the lowest AE from WBC oysters fed a diatom diet $(37.3 \%)$.

The effect of diatom concentration on AE was only determined for the July SQB and October HUM populations. The $\mathrm{AE}$ of $\mathrm{Cd}$ by the oysters decreased at higher diatom concentrations, and was particularly noticeable in the October HUM oysters (Table 1). The July experiment showed a weak negative relationship $\left(\mathrm{r}^{2}=0.47\right)$ between diatom concentration and $\mathrm{Cd} \mathrm{AE}$ because there was only a significant reduction of AE at the highest diatom concentration of $5 \mathrm{mg} \mathrm{l}^{-1}$ (Table 1). On the other hand, the HUM population showed a much stronger negative relationship $\left(\mathrm{r}^{2}=0.76\right)$ in $\mathrm{Cd}$ AEs, as diatom concentrations increased with a significant reduction of $\mathrm{AE}$ between diatom concentrations of
0.2 or $0.5 \mathrm{mg} \mathrm{l}^{-1}$ and $2 \mathrm{mg} \mathrm{l}^{-1}$, and between 2 or $5 \mathrm{mg}$ $\mathrm{l}^{-1}$ and $10 \mathrm{mg} \mathrm{l}^{-1}$ (Table 1).

\section{Dissolved uptake rate}

The rate of uptake of $\mathrm{Cd}$ from the dissolved phase increased with Cd concentrations in the water (Fig. 7). The regression was linear (log scale) for both July and October populations. There were marked differences in the uptake rate constants from the dissolved phase among the July populations ( $p<0.01$; Table 2$)$, with the exception of the NET and SQB populations, which had the highest constants. The ELD population had the lowest constant. The October populations had higher dissolved uptake rate constants than the July populations, and uptake rate constants among the October populations were similar except that SQB oysters had lower uptake. SQB oysters collected in July and October had comparable uptake rate constants ( $\mathrm{p}=0.51)$.

The body size of most July populations was negatively correlated to the uptake rate from the dissolved phase (5 out of 6 populations) (Table 3 ). The relationship was less obvious (significant regressions in 2 out of 4 populations) when oysters were pooled from the October populations at different concentrations of $\mathrm{Cd}$ (Table 3) and they showed positive relationships between body size and uptake of Cd. In general, the relationship between body size and uptake rate from the dissolved phase of oysters was population-dependent. 


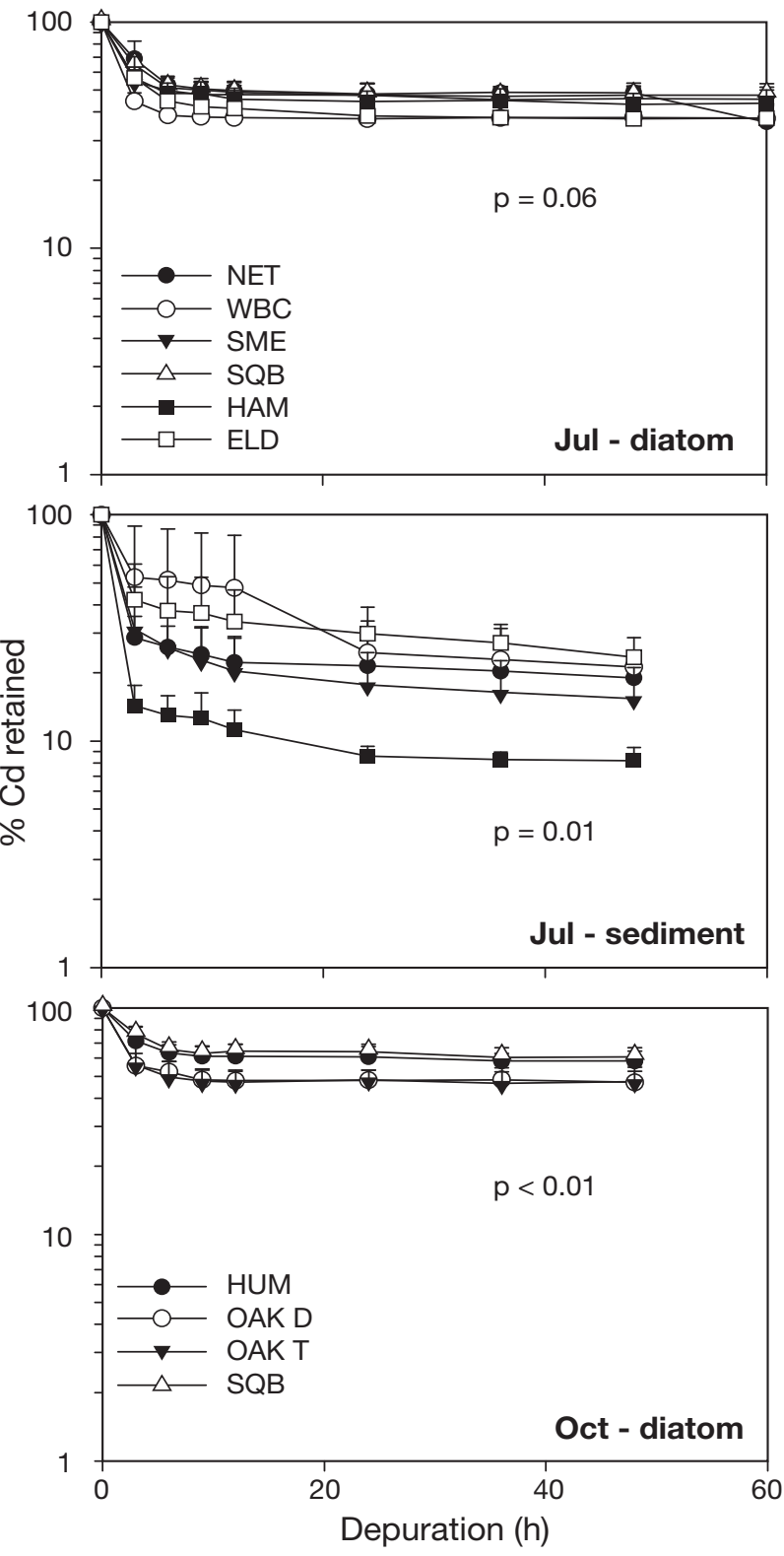

Fig. 6. Crassostrea gigas. Percentage of Cd retained (mean \pm $\mathrm{SD}_{i} \mathrm{n}=5$ ) in oysters after pulse feeding on diatoms (upper panel: July population, lower panel: October population) or sediment (middle panel: July population). Assimilation efficiency (AE) was determined as the percentage $\mathrm{Cd}$ retained at $24 \mathrm{~h}$. Significant differences in AE among populations were tested by ANOVA $(\mathrm{p}<0.05)$. OAK D: diploid seeds and OAK T: triploid seeds from Oakland Bay. See Fig. 1 for other site abbreviations

\section{Efflux}

Depuration or efflux of $\mathrm{Cd}$ after feeding on radiolabeled diatoms for $6 \mathrm{~d}$ followed a single compartment pattern over the $21 \mathrm{~d}$ depuration period (Fig. 8). The rate of loss among populations was significantly different $(p<0.05)$. ELD oysters had the fastest efflux rate of
Table 1. Crassostrea gigas. Assimilation efficiency (mean \pm $\mathrm{SD} ; \mathrm{n}=5$ ) of Cd by oysters fed different food types and concentrations. Food concentration for the food type experiment was 1 to $1.2 \mathrm{mg} \mathrm{l}^{-1}$ or $4 \times 10^{4}$ to $5 \times 10^{4}$ cells ml ${ }^{-1}$ (diatoms) and $10 \mathrm{mg} \mathrm{l}^{-1}$ (sediment). Assimilation efficiency of diatom at different food concentrations was only determined for the SQB (July) and HUM (October) populations. Data were not determined (nd) for the assimilation efficiency from sediment by SQB because they did not feed on sediment. One-way ANOVA and Tukey's multiple comparison post hoc test were only performed for differences within each food type and month of experiment. The same superscripted letter indicates no significant difference between treatments $(p>0.05)$. na: not applicable; OAK D: diploid seeds and OAK T: triploid seeds from Oakland Bay. See Fig. 1 for other site abbreviations

\begin{tabular}{|c|c|c|}
\hline & \multicolumn{2}{|c|}{ Assimilation efficiency (\%) for food type } \\
\hline & Diatom & Sediment \\
\hline \multicolumn{3}{|c|}{ Population } \\
\hline \multicolumn{3}{|c|}{ July experiment } \\
\hline NET & $48.1 \pm 5.7^{\mathrm{a}}$ & $21.5 \pm 7.6^{\mathrm{ab}}$ \\
\hline WBC & $37.3 \pm 5.9^{\mathrm{a}}$ & $24.6 \pm 9.3^{\mathrm{a}}$ \\
\hline SME & $47.4 \pm 6.0^{\mathrm{a}}$ & $17.7 \pm 6.9^{\mathrm{ab}}$ \\
\hline SQB & $47.6 \pm 5.7^{\mathrm{a}}$ & nd \\
\hline HAM & $44.6 \pm 5.0^{\mathrm{a}}$ & $8.6 \pm 0.9^{b}$ \\
\hline ELD & $38.5 \pm 6.7^{\mathrm{a}}$ & $29.9 \pm 9.2^{\mathrm{a}}$ \\
\hline \multicolumn{3}{|c|}{ October experiment } \\
\hline HUM & $60.8 \pm 6.9^{\mathrm{a}}$ & nd \\
\hline OAK D & $48.0 \pm 5.0^{\mathrm{b}}$ & nd \\
\hline OAK T & $48.0 \pm 5.0^{\mathrm{b}}$ & nd \\
\hline $\mathrm{SQB}$ & $64.2 \pm 4.8^{\mathrm{a}}$ & nd \\
\hline \multicolumn{3}{|c|}{ Diatom concentration $\left(\mathrm{mg} \mathrm{l}^{-1}\right)$} \\
\hline \multicolumn{3}{|c|}{ July experiment (SQB) } \\
\hline 0.2 & $38.7 \pm 7.4^{\mathrm{ab}}$ & na \\
\hline 0.5 & $40.5 \pm 5.8^{\mathrm{ab}}$ & na \\
\hline 2 & $40.6 \pm 4.0^{\mathrm{a}}$ & na \\
\hline 5 & $28.4 \pm 7.4^{\mathrm{b}}$ & na \\
\hline \multicolumn{3}{|c|}{ October experiment (HUM) } \\
\hline 0.2 & $55.9 \pm 9.5^{\mathrm{a}}$ & na \\
\hline 0.5 & $45.4 \pm 6.3^{\mathrm{ab}}$ & na \\
\hline 2 & $41.1 \pm 7.1^{\mathrm{b}}$ & na \\
\hline 5 & $44.0 \pm 4.3^{\mathrm{ab}}$ & na \\
\hline 10 & $17.9 \pm 2.6^{\mathrm{c}}$ & na \\
\hline
\end{tabular}

$0.024 \mathrm{~d}^{-1}$ while the depuration rates of $\mathrm{Cd}$ in the other populations were 2 times slower, ranging from 0.011 to $0.017 \mathrm{~d}^{-1}$ (Fig. 8).

\section{DISCUSSION}

MT is a common metal detoxification protein in bivalves and it is often induced by metals (Mason \& Jenkins 1996, Amiard et al. 2006). Higher Cd levels in the MTLP fraction may suggest that OAK oysters are more efficient at sequestering and hence detoxifiying $\mathrm{Cd}$ compared to the other groups of oysters. MT induction has been documented in oysters collected from contaminated environments or in laboratory exposure (Mouneyrac et al. 1998, Engel 1999), but whether MTs 


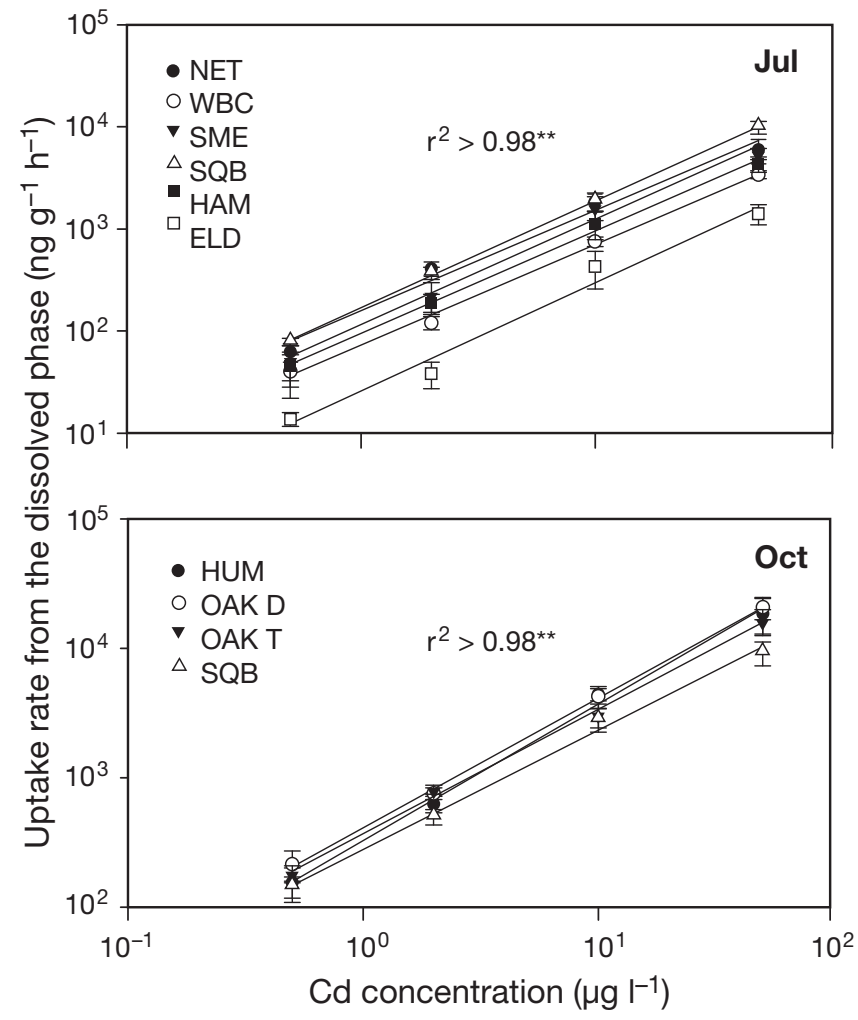

Fig. 7. Crassostrea gigas. Dissolved uptake rate of $\mathrm{Cd}$ (mean \pm $\mathrm{SD} ; \mathrm{n}=10$ ) by oysters from the July (upper panel) and October (lower panel) populations at different Cd concentrations. Lines were plotted when the regression coefficient $\left(\mathrm{r}^{2}\right)$ was $>0.50 .{ }^{* *}$ Significant difference at $\mathrm{p}<0.01$ (linear regression analysis). OAK D: diploid seeds and OAK T: triploid seeds from Oakland Bay. See Fig. 1 for other site abbreviations

Table 2. Crassostrea gigas. Dissolved Cd uptake rate constants (mean $\pm \mathrm{SD}_{i} \mathrm{n}=40$ ), calculated by dividing the dissolved uptake rate over the concentration of $\mathrm{Cd}$ in oysters exposed to different concentrations of Cd. Values sharing the same superscripted letter do not differ significantly by Tukey's multiple comparison post hoc test $(p>0.05)$. OAK D: diploid seeds and OAK T: triploid seeds from Oakland Bay. See Fig. 1 for other site abbreviations

\begin{tabular}{|lc|}
\hline Population & $\begin{array}{c}\text { Dissolved uptake rate constant } \\
\left(\mathrm{l} \mathrm{g}^{-1} \mathrm{~d}^{-1}\right)\end{array}$ \\
\hline July experiment & \\
NET & $3.76 \pm 1.20^{\mathrm{a}}$ \\
WBC & $1.71 \pm 0.54^{\mathrm{d}}$ \\
SME & $2.90 \pm 1.03^{\mathrm{b}}$ \\
SQB & $4.32 \pm 0.76^{\mathrm{a}}$ \\
HAM & $2.30 \pm 0.71^{\mathrm{c}}$ \\
ELD & $0.68 \pm 0.34^{\mathrm{e}}$ \\
October experiment & \\
HUM & $8.68 \pm 2.30^{\mathrm{a}}$ \\
OAK D & $9.59 \pm 1.90^{\mathrm{a}}$ \\
OAK T & $8.42 \pm 1.70^{\mathrm{a}}$ \\
SQB & $5.97 \pm 1.57^{\mathrm{b}}$ \\
\hline
\end{tabular}

Table 3. Crassostrea gigas. Regressions of the Cd uptake rate from the dissolved phase (ng g ${ }^{-1} \mathrm{~h}^{-1}$ ) and dry weight $(\mathrm{g})$ of oysters (y: uptake rate; $x$ : dry weight). Oysters collected in July and tested for uptake rate from the dissolved phase were exposed to $2 \mu \mathrm{g} \mathrm{l}^{-1} \mathrm{Cd}$ for different populations ( $\mathrm{n}=20 ; 0.01$ to $6 \mathrm{~g}$ dry wt), whereas populations of oysters collected in October were pooled and tested for uptake rate at $0.5,2,10$ and $50 \mu \mathrm{g} \mathrm{l}^{-1} \mathrm{Cd}(\mathrm{n}=40 ; 0.01$ to $0.15 \mathrm{~g}$ dry wt). The regression was tested by linear regression analysis. ${ }^{*} \mathrm{p}<0.05$ and ${ }^{* *} \mathrm{p}<0.01$ indicate significant regression. $r^{2}$ : regression coefficient. See Fig. 1 for site abbreviations

\begin{tabular}{|lll|}
\hline Population & Regression equation & $\mathrm{r}^{2}$ \\
\hline July experiment & & \\
NET & $\log y=0.14 \log x+2.77$ & 0.16 \\
WBC & $\log y=-0.27 \log x+1.44$ & $0.49^{* *}$ \\
SME & $\log y=-0.15 \log x+1.83$ & $0.27^{*}$ \\
SQB & $\log y=-0.95 \log x+0.92$ & $0.75^{* *}$ \\
HAM & $\log y=-0.22 \log x+1.85$ & $0.54^{* *}$ \\
ELD & $\log y=-0.28 \log x+1.46$ & $0.63^{* *}$ \\
October experiment & & \\
$0.5 \mu \mathrm{g} \mathrm{l}^{-1} \mathrm{Cd}$ & $\log y=4.44 x+2.10$ & $0.22^{* *}$ \\
$2 \mu \mathrm{I} \mathrm{l}^{-1} \mathrm{Cd}$ & $\log y=3.78 x+2.71$ & $0.49^{* *}$ \\
$10 \mu \mathrm{g} \mathrm{l}^{-1} \mathrm{Cd}$ & $\log y=-0.93 x+3.57$ & 0.04 \\
$50 \mu \mathrm{l} \mathrm{l}^{-1} \mathrm{Cd}$ & $\log y=1.01 x+4.15$ & 0.02 \\
\hline
\end{tabular}

can be used as a biomarker of Cd contamination in the environment has been questioned (Geffard et al. 2001, Geret \& Cosson 2002). Crassostrea gigas in the chronically Cd-contaminated site Gironde estuary (France) stored 40 to $60 \% \mathrm{Cd}$ in the soluble form and 30 to $40 \%$ of this fraction associated with the MTs (Boisson et al. 2003). This chelation may reduce the toxicity of $\mathrm{Cd}$ to

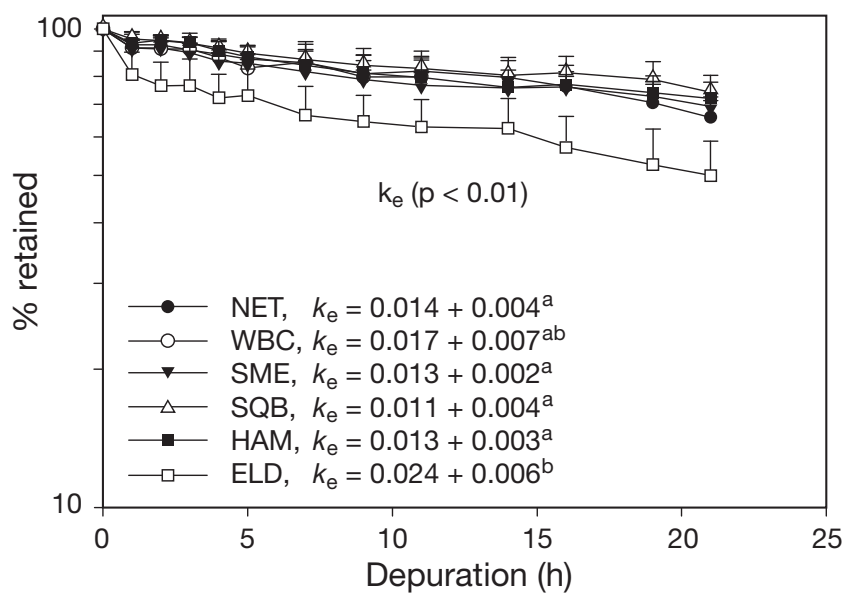

Fig. 8. Crassostrea gigas. Depuration of $\mathrm{Cd}($ mean $\pm \mathrm{SD} ; \mathrm{n}=5$ ) by the July population of oysters after feeding on diatoms for $6 \mathrm{~d}$. Efflux rate constant $\left(k_{\mathrm{e}}, \mathrm{d}^{-1}\right)$ was calculated from the slope of the linear regression between the $\mathrm{ln} \% \mathrm{Cd}$ retained in the oysters against the depuration time (d). Significant difference of $k_{\mathrm{e}}$ among populations was tested by ANOVA ( $\left.\mathrm{p}<0.05\right) ; k_{\mathrm{e}}$ for populations with the same letter did not differ significantly (Tukey's multiple comparison post hoc test; $p>0.05$ ). See Fig. 1 for site abbreviations 
oysters. The high association of Cd with the MTLP fraction may also imply a high bioavailability of $\mathrm{Cd}$ to the next trophic level (Wallace \& Luoma 2003).

Clearance rate or pumping activity can indicate the physiological condition of bivalves and can be affected by toxic effects of metals (Naimo 1995, Alves \& Wood 2006). Vice versa, clearance rate also affects metal accumulation in the bivalves. A higher clearance rate (or water pumping rate) may lead to more metals passing through the gills, as well as more food passing through the gut. The October populations in general had a higher clearance rate than the July populations. Such biological variation may be caused by seasonal fluctuation in food availability or biological adaptation to local food availability. For example, a lower food availability in late autumn (October) than in summer (July) may lead to a faster pumping rate to attain more food for metabolic requirements. However, field measurements are needed to confirm the hypothesis. Despite a higher clearance rate, the October populations had similar body conditions as the July populations.

The present study found that there was variation in $\mathrm{Cd}$ uptake from the dissolved phase among populations of the oysters. Such inter-population difference of Cd kinetics has also been previously shown for oysters (Crassostrea iredalei and C. belcheri) cultured at 2 different locations (Lim et al. 1998) and for C. gigas originating from a clean or contaminated bay during $21 \mathrm{~d}$ exposure to both waterborne and diet-borne Cd (Boisson et al. 2003). In addition, the relationship between clearance rate and uptake from the dissolved phase was population-dependent; for instance, SQB oysters had the highest uptake rate constant within the July population, but HUM oysters had the highest clearance rate. However, the lowest uptake constant was observed for ELD oysters, which had a low clearance rate. The October populations also had higher uptake constants and clearance rates than the July populations. In general, the oysters had 3 to 10 times higher $\mathrm{Cd}$ uptake rate constant from the dissolved phase than the other bivalves of similar sizes such as mussels, clams, and scallops (Pan \& Wang 2008b). Simultaneously, they had higher clearance rate $\left(10\right.$ to $\left.80 \mathrm{l} \mathrm{g}^{-1} \mathrm{~h}^{-1}\right)$ than the other bivalves (typical clearance rate for clams and mussels: 1 to $10 \mathrm{l} \mathrm{g}^{-1} \mathrm{~h}^{-1}$ ), except for scallops (42 to $124 \mathrm{l} \mathrm{g}^{-1} \mathrm{~h}^{-1}$ ). However, the intra-specific difference in clearance rate cannot completely account for the difference in metal uptake rate constants among the bivalves (Chong \& Wang 2001). Smaller oysters had higher $\mathrm{Cd}$ uptake rate than the larger oysters in the July populations, similar to that observed for $\mathrm{Cd}$ and zinc (Zn) uptake in mussels, clams, and scallops (Lee et al. 1998, Wang \& Dei 1999, Pan \& Wang 2008b). In these bivalves, the influx rate decreased in a power function with increasing body size, which may be caused by size-specific metabolic rates (Boyden 1974, Ringwood 1989, Newman \& Heagler 1991) or changes in gill surface area. However, this relationship was not observed for the October populations. In fact, positive, negative, or no relationships may be found between tissue metal concentration and bivalve size in natural populations, and such a relationship is complicated by the effects of growth and long-term changes in metal partitioning among intracellular components.

Uptake of metals from diet can be a significant route of metal accumulation in bivalves. For clams and scallops, trophic transfer is more important than uptake from the dissolved phase in the overall $\mathrm{Cd}$ and $\mathrm{Zn}$ accumulation because they have relatively high $\mathrm{Cd}$ and $\mathrm{Zn} \mathrm{AE}$ and low uptake rate constant from the dissolved phase (Chong \& Wang 2001, Pan \& Wang 2008b). Assimilation of metals from phytoplankton by oysters is generally higher than in mussels and clams (Reinfelder et al. 1997, Wang 2003). However, assimilation of $\mathrm{Cd}$ in oysters is not as high as that by the scallop Chlamys nobilis (>86\%) (Pan \& Wang 2008b). Cd uptake from the diet may be the main exposure pathway for the oysters, given the high Cd dietary AE. The metal AE generally depends on the gut chemistry and physiology of bivalves, e.g. gut $\mathrm{pH}$ and passage time. The oysters Cd AEs from sediment and diatom diets were population-dependent, implying that oyster gut physiology and biochemistry from different sites may be somewhat different. Generally, AE of metals is lower from sediment than from living matter like phytoplankton (Wang \& Wong 2003) because surfacebound metals on sediment move more quickly through the digestive tracts. In the present study, the sediment was dried before being radiolabeled. This may change the physical or chemical properties of sediment and affect the bioavailability of $\mathrm{Cd}$. However, $\mathrm{Cd}$ in suspended particles or sediment has been reported to be not significant for $\mathrm{Cd}$ accumulation in Crassostrea gigas (Lekhi et al. 2008, Widmeyer \& Bendell-Young 2008). Wang \& Wong (2003) found that the Cd AE was more influenced by the quality (in terms of organic carbon concentration) than quantity of food in Perna viridis. $\mathrm{Cd}$ uptake from phytoplankton with different concentrations may be dependent on population of oysters, with SQB oysters showing a weak relationship and HUM a strong relationship. On the other hand, the difference in results between populations may be explained by a lack of higher diatom concentration (10 mg $\mathrm{l}^{-1}$ ) tested in the July experiment, as the relationship was improved by a higher diatom concentration in the October experiment. Higher food concentration may have reduced the $\mathrm{AE}$ of metals in oysters because there was relatively shorter gut retention time at high food concentration, thus it was probably less efficient 
for the oysters to digest and absorb the food. In view of this, oysters living in a higher food-concentration environment may have similar accumulation of $\mathrm{Cd}$ from diet as oysters living in a low food-concentration environment. That is, the effect of high food quantity on metal assimilation in oysters is cancelled out by the effect of higher assimilation of metal at low food quantities.

The excretion of metals by bivalves is generally independent of environmental conditions (Wang 2003); this was also true for oysters collected from different sites in the present study. Typical efflux rate constants in bivalves are within 0.01 to $0.03 \mathrm{~d}^{-1}$ and the interspecies variation in metal efflux rate is rather small. However, variations in metal efflux rate have been reported among oysters collected from coastal and estuarine zones. The coastal oyster Saccostrea glomerata had relatively lower $\mathrm{Cd}$ and $\mathrm{Zn}$ efflux rates than the estuarine oyster Crassostrea rivularis (Ke \& Wang 2001). The efflux measured by stable Cd tissue analysis using transplant methodology in the field is generally longer than that measured under laboratory conditions using radiotracer techniques. For example, Geffard et al. (2002) reported a biological half-life of Cd in C. gigas of 86 to $251 \mathrm{~d}$ (or 0.003 to $0.008 \mathrm{~d}^{-1}$ ). It should be noted that $\mathrm{Cd}$ retention in the oysters may have been confounded by $\mathrm{Cd}$ uptake during the transplant period, thus the calculated Cd efflux may be higher than the unidirectional efflux measured using Cd radiotracer.

The biokinetics of Cd may explain the difference in accumulation, primarily within the July oyster populations. ELD oysters depurated $\mathrm{Cd}$ the fastest, and also had the slowest uptake rate constants from the aqueous phase, which therefore may have contributed to the low Cd accumulated in the soft tissue. NET oysters had the highest dissolved uptake rate constant, which may relate to the higher accumulation among other populations. October populations generally had higher dissolved uptake rate constants than the July populations, which may have resulted in higher soft tissue $\mathrm{Cd}$ concentrations.

The diploid and triploid OAK oysters had similar Cd kinetics and storage of $\mathrm{Cd}$ in their subcellular compartments, despite the genetic variation. Genetically, triploid oysters are made partially sterile so that a change in allocation of energy from reproduction enables them to have better growth rates. In addition, the triploid oysters may be more resistant to diseases and associated mortality caused by parasites (Nell 2002). In the present study, the only biological difference observed between the triploid and diploid OAK oysters was the 1.5 to 2 times heavier tissue dry weight of the triploids than the diploids, despite having a comparable size in shell length. In addition, diploids fil- tered water 3 times faster than triploids. These biological differences apparently did not affect the $\mathrm{Cd}$ accumulation or excretion in the 2 genetically different oysters. Amiard et al. (2005) in fact hypothesized that the higher energy available for growth in triploid oysters may have a positive impact on the metal detoxification and excretion since transcription is faster with 3 copies of each gene. The positive role of heterozygosity on feeding rate and absorption efficiency has also been emphasized by Hawkins et al. (2000). However, the triploid Crassostrea gigas had a lower Ag, Cd, and copper $(\mathrm{Cu})$ accumulation in the study by Amiard et al. (2005), probably due to the physiological changes associated with the reproductive development of the diploids. On the other hand, Marie et al. (2006) reported no significant difference in MT gene expression, MT protein synthesis, and $\mathrm{Cd}$ accumulation in the gills of diploid and triploid C. gigas. These results are consistent with our results on MT concentration in the oysters, suggesting that the triploid oysters had the same capacity to respond to $\mathrm{Cd}$ as did the diploids.

To summarize, there was an inter-population difference of $\mathrm{Cd}$ accumulation in the Pacific oyster Crassostrea gigas, but the populations were similar in $\mathrm{Cd}$ detoxification and storage. The difference in $\mathrm{Cd}$ accumulation may be partially explained by the difference in Cd uptake from food (as indicated by clearance rate and $\mathrm{AE}$ ) and water (indicated by $\mathrm{Cd}$ dissolved uptake constants). Uptake of $\mathrm{Cd}$ from food relied on the food quality (diatoms vs. sediment) and concentration (diatoms) in the environment, whereas uptake from the dissolved phase relied on ambient $\mathrm{Cd}$ concentrations and body size of oysters. Therefore, field data such as ambient Cd concentrations, food particle concentration and composition, and growth of oysters are important for further understanding of the interpopulation difference of $\mathrm{Cd}$ accumulation in the oysters. The present study provides the basic information (Cd kinetic constants and variables for these constants) for building a biokinetic model. Field measurements will complete the model and validate it for monitoring Cd contamination in oysters.

Acknowledgements. We greatly acknowledge the anonymous reviewers for their very detailed and constructive comments on this work. This study was funded in part by the USDA Cooperative State Research Education and Extension Service Award No. 2004-51110-02156, and the General Research Fund from the Hong Kong Research Grants Council (HKUST6420/06M).

\section{LITERATURE CITED}

Alves LC, Wood CM (2006) The chronic effects of dietary lead in freshwater juvenile rainbow trout (Oncorhynchus mykiss) fed elevated calcium diets. Aquat Toxicol 78:217-232 
Amiard JC, Perrein-Ettajani H, Gerard A, Baud JP, AmiardTriquet C (2005) Influence of ploidy and metal-metal interactions on the accumulation of $\mathrm{Ag}, \mathrm{Cd}$, and $\mathrm{Cu}$ in oysters Crassostrea gigas Thunberg. Arch Environ Contam Toxicol 48:68-74

Amiard JC, Amiard-Triquet C, Barka S, Pellerin J, Rainbow PS (2006) Metallothioneins in aquatic invertebrates: their role in metal detoxification and their use as biomarkers. Aquat Toxicol 76:160-202

Ayling GM (1974) Uptake of cadmium, zinc, copper, lead and chromium in Pacific oyster, Crassostrea gigas, grown in Tamar river, Tasmania. Water Res 8:729-738

Blackmore G, Wang WX (2003) Comparison of metal accumulation in mussels at different local and global scales. Environ Toxicol Chem 22:388-395

Boisson F, Goudard F, Durand JP, Barbot C, Pieri J, Amiard JC, Fowler SW (2003) Comparative radiotracer study of cadmium uptake, storage, detoxification and depuration in the oyster Crassostrea gigas: potential adaptive mechanisms. Mar Ecol Prog Ser 254:177-186

Boyden CR (1974) Trace metal content and body size in molluscs. Nature 251:311-314

> Chong K, Wang WX (2001) Comparative studies on the biokinetics of $\mathrm{Cd}, \mathrm{Cr}$, and $\mathrm{Zn}$ in the green mussel Perna viridis and the Manila clam Ruditapes philippinarum. Environ Pollut 115:107-121

Codex (2007) Codex Alimentarius Commission Report, 38th session, Joint FAO/WHO Food Standards Programme, Geneva

Denton GRW, Burdon-Jones C (1981) Influence of temperature and salinity on the uptake, distribution and depuration of mercury, cadmium and lead by the black-lip oyster Saccostrea echinata. Mar Biol 64:317-326

Engel DW (1999) Accumulation and cytosolic partitioning of metals in the American oyster Crassostrea virginica. Mar Environ Res 47:89-102

> Geffard A, Amiard-Triquet C, Amiard JC, Mouneyrac C (2001) Temporal variations of metallothionein and metal concentrations in the digestive gland of oysters (Crassostrea gigas) from a clean and a metal-rich site. Biomarkers 6:91-107

Geffard A, Amiard JC, Amiard-Triquet C (2002) Kinetics of metal elimination in feral oysters from a contaminated estuary: implications in food hygiene. Comp Biochem Physiol C 131:281-293

> Geret F, Cosson RP (2002) Induction of specific isoforms of metallothionein in mussel tissues after exposure to cadmium or mercury. Arch Environ Contam Toxicol 42:36-42

Hawkins AJ, Magoulas A, Heral M, Bougrier S, NaciriGraven Y, Day AJ (2000) Separate effect of triploidy, percentage and genomic diversity upon feeding behaviour, metabolic efficiency and net energy balance in the Pacific oyster Crassostrea gigas. Genet Res 76:273-284

Ke C, Wang WX (2001) Bioaccumulation of Cd, Se and Zn in an estuarine oyster (Crassostrea rivularis) and a coastal oyster (Saccostrea glomerata). Aquat Toxicol 56:33-51

> Lee BG, Wallace WG, Luoma SN (1998) Uptake and loss kinetics of $\mathrm{Cd}, \mathrm{Cr}$ and $\mathrm{Zn}$ in the bivalves Potamocorbula amurensis and Macoma balthica: effects of size and salinity. Mar Ecol Prog Ser 175:177-189

Lekhi P, Cassis D, Pearce CM, Ebell N, Maldonado MT, Orians KJ (2008) Role of dissolved and particulate cadmium in the accumulation of cadmium in cultured oysters (Crassostrea gigas). Sci Total Environ 393:309-325

Leung KMY, Furness RW (1999) Induction of metallothionein in dogwhelk Nucella lapillus during and after exposure to cadmium. Ecotoxicol Environ Saf 43:156-164
Lim PE, Lee CK, Din Z (1998) The kinetics of bioaccumulation of zinc, copper, lead and cadmium by oysters (Crassostrea iredalei and $C$. belcheri) under tropical field conditions. Sci Total Environ 216:147-157

- Luoma SN, Rainbow PS (2005) Why is bioaccumulation so variable? Biodynamics as a unifying principle. Environ Sci Technol 39:1921-1931

Luoma SN, Rainbow PS (2008) Metal contamination in aquatic environments - Science and lateral management. Cambridge University Press, New York

Marie V, Gonzalez P, Baudrimont M, Boutet I, Moraga D, Bourdineaud JP, Boudou A (2006) Metallothionein gene expression and protein levels in triploid and diploid oysters Crassostrea gigas after exposure to cadmium and zinc. Environ Toxicol Chem 25:412-418

Mason AZ, Jenkins KD (1996) Metal detoxification in aquatic organisms. In: Tessier A, Turner DR (eds) Metal speciation and bioavailability in aquatic systems. Wiley, Chichester, p 479-608

> Mouneyrac C, Amiard JC, Amiard-Triquet C (1998) Effects of natural factors (salinity and body weight) on cadmium, copper, zinc and metallothionein-like protein levels in resident populations of oysters Crassostrea gigas from a polluted estuary. Mar Ecol Prog Ser 162:125-135

> Naimo TJ (1995) A review of the effects of heavy metals on freshwater mussels. Ecotoxicology 4:341-362

Nell JA (2002) Farming triploid oysters. Aquaculture 210: 69-88

Newman MC, Heagler MG (1991) Allometry of metal bioaccumulation and toxicity. In: Newman MC, Mcintosh AW (eds) Metal ecotoxicity: concepts and applications. Lewis Publishers, Chelsea, MI, p 91-130

Ng TYT, Wang WX (2005a) Modeling of cadmium bioaccumulation in two populations of the green mussel Perna viridis. Environ Toxicol Chem 24:2299-2305

$>$ Ng TYT, Wang WX (2005b) Subcellular controls of silver biokinetics in the green mussel Perna viridis from two hydrographic zones. Mar Ecol Prog Ser 299:193-204

> Pan K, Wang WX (2008a) Validation of biokinetic model of metals in the scallop Chlamys nobilis in complex field environments. Environ Sci Technol 42:6285-6290

Pan K, Wang WX (2008b) Allometry of cadmium and zinc concentrations and bioaccumulation in the scallop Chlamys nobilis. Mar Ecol Prog Ser 365:115-126

> Rainbow PS, Smith BD, Luoma SN (2009) Differences in trace metal bioaccumulation kinetics among populations of the polychaete Nereis diversicolor from metal-contaminated estuaries. Mar Ecol Prog Ser 376:173-184

Reinfelder JR, Wang WX, Fisher NS, Luoma SN (1997) Assimilation efficiency and turnover rates of trace elements in marine bivalves: a comparison of oysters, clams and mussels. Mar Biol 129:443-452

> Ringwood AH (1989) Accumulation of cadmium by larvae and adults of an Hawaiian bivalve, Isognomon californicum, during chronic exposure. Mar Biol 102:499-504

> Roditi HA, Fisher NS, Sanudo-Wilhelmy SA (2000) Field testing a metal bioaccumulation model for zebra mussels. Environ Sci Technol 34:2817-2825

Scheuhammer AM, Cherian MG (1986) Quantification of metallothioneins by a silver-saturation method. Toxicol Appl Pharmacol 82:417-425

Scheuhammer AM, Cherian MG (1991) Quantification of metallothionein by silver saturation. Methods Enzymol 205: 78-83

USFDA (2005) 2005.04 Action levels, tolerances and guidance levels for poisonous or deleterious substances in seafood. Chapter II: Growing areas. IV. Guidance documents. 
National shellfish sanitation program, Centre for food and applied nutrition, Washington DC

Wallace WG, Luoma SN (2003) Subcellular compartmentalization of Cd and $\mathrm{Zn}$ in two bivalves. II. Significance of trophically available metal (TAM). Mar Ecol Prog Ser 257: 125-137

Wallace WG, Lee BG, Luoma SN (2003) Subcellular compartmentalization of $\mathrm{Cd}$ and $\mathrm{Zn}$ in two bivalves. I. Significance of metal-sensitive fractions (MSF) and biologically detoxified metal (BDM). Mar Ecol Prog Ser 249:183-197

Wallner-Kersanach M, Theede H, Eversberg U, Lobo S (2000) Accumulation and elimination of trace metals in a transplantation experiment with Crassostrea rhizophorae. Arch Environ Contam Toxicol 38:40-45

Wang WX (2002) Interactions of trace metals and different marine food chains. Mar Ecol Prog Ser 243:295-309

Wang WX (2003) Metal bioaccumulation in bivalve mollusks: recent progress. In: Villalba A, Reguera B, Romalde JL, Beiras R (eds) Molluscan shellfish safety. Intergovernmental Oceanographic Commission of UNESCO and Conselleria de Pesca e Asuntos Maritimos da Xunta de Galicia, Santiago de Compostela, p 503-520

Wang WX (2009) Metals and organic contaminants in bivalve

Editorial responsibility: Hans Heinrich Janssen, Oldendorf/Luhe, Germany molluscs. In: Shumway S, Rodrick G (eds) Shellfish safety and quality. CRC Press, Boca Raton, FL, p 228-247

Wang WX, Dei RCH (1999) Factors affecting trace element uptake in the black mussel Septifer virgatus. Mar Ecol Prog Ser 186:161-172

Wang WX, Fisher NS (1996) Assimilation of trace elements and carbon by the mussel Mytilus edulis: effects of food composition. Limnol Oceanogr 41:197-207

Wang WX, Rainbow PS (2008) Comparative approaches to understand metal bioaccumulation in aquatic animals. Comp Biochem Physiol C 148:315-323

- Wang WX, Wong SK (2003) Combined effects of food quantity and quality on $\mathrm{Cd}, \mathrm{Cr}$, and $\mathrm{Zn}$ assimilation to the green mussel, Perna viridis. J Exp Mar Biol Ecol 290: 49-69

Widdows J, Fieth P, Worrall CM (1979) Relationships between seston, available food and feeding activity in the common mussel Mytilus edulis. Mar Biol 50:195-207

Widmeyer JR, Bendell-Young LI (2008) Heavy metal levels in suspended sediments, Crassostrea gigas, and the risk to humans. Arch Environ Contam Toxicol 55:442-452

Zaroogian GE, Cheer SA (1976) Accumulation of cadmium by American oyster Crassostrea virginica. Nature 261:408-410

Submitted: July 3, 2009; Accepted: November 4, 2009

Proofs received from author(s): February 10, 2010 